\title{
The crystal structure of szenicsite, $\mathrm{Cu}_{3} \mathrm{MoO}_{4}(\mathrm{OH})_{4}$
}

\author{
Peter C. Burns
}

Department of Civil Engineering and Geological Sciences, University of Notre Dame, Notre Dame, Indiana 46556-0767, USA

\section{ABSTRACT}

The crystal structure of szenicsite, $\mathrm{Cu}_{3} \mathrm{MoO}_{4}(\mathrm{OH})_{4}$, orthorhombic, $a=8.5201(8), b=12.545(1), c=$ 6.0794(6) $\AA, V=649.8(2) \AA^{3}$, space group Pnnm, $Z=4$, has been solved by direct methods and refined by least-squares techniques to an agreement index $(R)$ of $3.34 \%$ and a goodness-of-fit $(S)$ of 1.11 for 686 unique observed $\left[|F| \geqslant 4 \sigma_{F}\right]$ reflections collected using graphite-monochromated Mo-K $\alpha \mathrm{X}$ radiation and a $\mathrm{CCD}$ area detector. The structure contains three unique $\mathrm{Cu}^{2+}$ positions that are each coordinated by six anions in distorted octahedral arrangements; the distortions of the octahedra are due to the Jahn-Teller effect associated with a $d^{9}$ metal in an octahedral ligand-field. The single unique $\mathrm{Mo}^{6+}$ position is tetrahedrally coordinated by four $\mathrm{O}^{2-}$ anions. The $\mathrm{Cu}^{2+} \phi_{6}(\phi$ : unspecified ligand) octahedra share trans edges to form rutile-like chains, three of which join by the sharing of octahedral edges to form triple chains that are parallel to [001]. The $\mathrm{MoO}_{4}$ tetrahedra are linked to either side of the triple chain of $\mathrm{Cu}^{2+} \phi_{6}$ octahedra by the sharing of two vertices per tetrahedron, and the resulting chains are cross-linked through tetrahedral-octahedral vertex sharing to form a framework structure. The structure of szenicsite is closely related to that of antlerite, $\mathrm{Cu}_{3} \mathrm{SO}_{4}(\mathrm{OH})_{4}$, which contains similar triple chains of edge-sharing $\mathrm{Cu}^{2+} \phi_{6}$ octahedra.

KEYWORDS: szenicsite, copper oxysalt, crystal structure, molybdate, Chile.

\section{Introduction}

Szenicsite, $\mathrm{Cu}_{3} \mathrm{MoO}_{4}(\mathrm{OH})_{4}$, was recently described by Francis et al. (1997). Large crystals of szenicsite occur at the only known locality, the Jardinera No. 1 mine in Chile's Atacama province, where it is associated with powellite as fracture fillings and as crystals in vugs in a hydrothermally altered granitic matrix (Francis $e t$ al., 1997). The large (1 cm diameter) crystals of szenicsite facilitate $\mathrm{X}$-ray diffraction studies; the results of a crystal-structure determination are presented herein.

\section{Experimental}

A sample containing several large $(\sim 1 \mathrm{~cm}$ diameter) crystals of szenicsite, originating from the Atacama province of Chile, was obtained from the Geological Survey of Canada number 67409). A crystal fragment with dimensions $0.30 \times 0.10 \times 0.04 \mathrm{~mm}$ was selected for study. The crystal was mounted on a Siemens
PLATFORM goniometer equipped with a $1 \mathrm{~K}$ SMART CCD (charge-coupled device) detector with a crystal-to-detector distance of five $\mathrm{cm}$. The $1 \mathrm{~K}$ SMART CCD detector is a two-dimensional area detector with a nine $\mathrm{cm}$ diameter activeimaging area. The CCD detector provides improved resolution, sensitivity to weak reflections, and shorter data collection times as compared to a scintillation detector mounted on a serial diffractometer.

The data were collected using monochromatic Mo- $K \alpha \mathrm{X}$-radiation and $\omega$ scans (frame widths) of $0.3^{\circ}$, with $10 \mathrm{~s}$ used to acquire each frame. More than a hemisphere of three-dimensional data was collected and the data were analysed to locate peaks for the determination of the unit-cell dimensions. The unit-cell dimensions (Table 1) were refined with 2230 reflections using leastsquares techniques. Data were collected for $3^{\circ} \leqslant$ $2 \theta \leqslant 58.5^{\circ}$ and covered the index ranges $10 \leqslant h$ $\leqslant 10,-15 \leqslant k \leqslant 13,-7 \leqslant l \leqslant 6$. The data were collected in approximately six hours and the intensities of the standard reflections showed no 
TABLE 1. Miscellaneous information for szenicsite

\begin{tabular}{llll}
\hline$a(\AA)$ & $8.5201(8)$ & Crystal size $(\mathrm{mm})$ & $0.30 \times 0.10$ \\
$b(\AA)$ & $12.545(1)$ & & $\times 0.04$ \\
$c(\AA)$ & $6.0794(6)$ & Total Ref. & 3380 \\
$V\left(\AA^{3}\right)$ & $649.8(2)$ & Unique Ref. & 743 \\
Space group & $P n n m$ & $R_{\text {int }}$ & 4.41 \\
$F(000)$ & 788 & Unique $\left|F_{\mathrm{o}}\right| \geqslant 4 \sigma_{F}$ & 686 \\
$\mathrm{D}_{\text {calc }}$ & $4.279 \mathrm{~g}^{3} \mathrm{~cm}^{3}$ & Final $R$ & 3.34 \\
$\mu$ & $11.57 \mathrm{~mm}^{-1}$ & Final $S$ & 1.11 \\
Unit-cell contents: $4\left\{\mathrm{Cu}_{3} \mathrm{MoO}_{4}(\mathrm{OH})_{4}\right\}$ & & \\
& & & \\
\hline
\end{tabular}

$R=\Sigma\left(\left|F_{\mathrm{o}}\right|-\left|F_{\mathrm{c}}\right|\right) / \Sigma\left|F_{\mathrm{o}}\right|$

$S=\left[\Sigma w\left(\left|F_{\mathrm{o}}\right|-\left|F_{\mathrm{c}}\right|\right)^{2} /(m-n)\right]^{\hat{Y}}$, for $m$ observations and $n$ parameters

significant change during the data collection. The data were corrected for Lorentz, polarization, and background effects. An empirical absorptioncorrection was done based upon 1528 intense reflections. The crystal was modeled as an ellipse, lowering $R_{\text {azimuthal }}$ of the 1528 intense reflections from 5.35 to $3.94 \%$. A total of 3380 reflections was collected, of which there were 743 unique reflections with 686 classed as observed $\left[|F| \geqslant 4 \sigma_{F}\right]$.

\section{Structure solution and refinement}

Scattering curves for neutral atoms, together with anomalous dispersion corrections, were taken from International Tables for X-Ray Crystallography, Vol. IV (Ibers and Hamilton, 1974). The Siemens SHELXTL Version 5 system of programs was used for the determination and refinement of the crystal structure.

Reflection statistics indicated the space groups Pnnm or Pnn2, and assigning phases to a set of normalized structure-factors gave a mean value $\left|E^{2}-1\right|$ of 0.946 , indicating the space group Pnnm. The space group Pnnm was verified by the successful solution of the structure by direct methods. Refinement of all atomic-positional parameters, and allowing for isotropic atomicdisplacement, gave a model with an agreement index $(R)$ of $6.08 \%$. Conversion of the displacement parameters to anisotropic, together with the inclusion of a refinable weighting-scheme of the structure factors, provided a model with an $R$ of $3.44 \%$. At this stage of the refinement the locations of three $\mathrm{H}$ atoms were obtained from difference-Fourier maps, and their positional parameters were added to the refinement. The final model gave an $R$ of $3.34 \%$ for 686 observed reflections $\left[|F| \geqslant 4 \sigma_{F}\right]$ and a goodness-of-fit $(S)$ of 1.11. The maximum peak and trough in the difference-Fouriermaps were 1.3 and $-0.85 \mathrm{e} / \AA^{3}$, respectively. The final atomic-positional parameters and anisotropic-displacement parameters are given in Table 2, selected interatomic distances and angles are given in Table 3 , and a bond-valence analysis is given in Table 4. A list of calculated and observed structure factors has been deposited with the editor of Mineralogical Magazine and is available on request.

\section{Discussion}

\section{Cation coordination}

There are three symmetrically distinct $\mathrm{Cu}^{2+}$ positions in the structure; each is coordinated by six anions in a distorted-octahedral arrangement. All three $\mathrm{Cu}^{2+} \phi_{6}(\phi$ : unspecified anion) octahedra are elongated, such that there are four short $(\sim 1.95 \AA)$ equatorial bonds and two longer $(\sim 2.3 \AA)$ apical bonds, a $(4+2)$ distortion. Virtually all $\mathrm{Cu}^{2+} \phi_{6}$ octahedra in mineral structures are similarly distorted (Burns and Hawthorne, 1996), owing to the well-known Jahn-Teller effect (Jahn and Teller, 1937) that is associated with the electronic energy-degeneracy of a $d^{9}$ cation in an octahedral ligand-field.

The $\mathrm{Cu} 3 \phi_{6}$ octahedron contains only $(\mathrm{OH})^{-}$ anions, and the $<\mathrm{Cu}^{2+}-\mathrm{OH}>$ bond-length is $2.092 \AA$, with a calculated bond-valence sum at the $\mathrm{Cu}^{2+}$ site of $1.98 v u$ (Table 4). The remaining two $\mathrm{Cu}^{2+} \phi_{6}$ octahedra contain both $\mathrm{O}^{2-}$ and $(\mathrm{OH})^{-}$anions, with the apical positions of the $(4+2)$-distorted octahedra occupied by $\mathrm{O}^{2-}$ anions. The $\mathrm{Cu}_{1} \mathrm{O}_{3}(\mathrm{OH})_{3}$ and $\mathrm{Cu}_{2} \mathrm{O}_{2}(\mathrm{OH})_{4}$ octahedra have $\left\langle\mathrm{Cu}^{2+}{ }_{-} \phi\right\rangle$ bond-lengths of 2.099 and $2.115 \AA$, respectively, and the bond- 
TABLE 2. Final atomic parameters for szenicsite

\begin{tabular}{|c|c|c|c|c|c|c|c|c|c|c|}
\hline & $x$ & $y$ & $z$ & $* U_{\mathrm{eq}}$ & $* * U_{11}$ & $U_{22}$ & $U_{33}$ & $U_{12}$ & $U_{13}$ & $U_{23}$ \\
\hline $\mathrm{Cu} 1$ & $0.26870(9)$ & $0.13257(5)$ & $-0.2495(1)$ & $142(2)$ & 203(4) & $128(4)$ & $94(4)$ & $-15(2)$ & $3(3)$ & $3(2)$ \\
\hline $\mathrm{Cu} 2$ & 0 & 0 & $-\hat{Y}$ & $144(3)$ & $217(7)$ & $129(6)$ & $85(6)$ & $-31(5)$ & 0 & 0 \\
\hline $\mathrm{Cu} 3$ & 0 & 0 & 0 & $151(3)$ & $229(7)$ & $149(6)$ & $76(6)$ & $-25(5)$ & 0 & 0 \\
\hline Mo & $0.12421(9)$ & $0.36909(5)$ & 0 & $142(2)$ & $198(4)$ & $125(4)$ & 103(3) & $6(2)$ & 0 & 0 \\
\hline $\mathrm{O} 1$ & $0.2673(7)$ & $0.2687(4)$ & 0 & $177(11)$ & $240(30)$ & $121(26)$ & $170(26)$ & $5(20)$ & 0 & 0 \\
\hline $\mathrm{O} 2$ & $0.0086(6)$ & $0.3575(4)$ & $0.2380(6)$ & $214(10)$ & $223(22)$ & $265(23)$ & $154(20)$ & $30(17)$ & $-10(18)$ & $2(15)$ \\
\hline $\mathrm{O} 3$ & $0.2223(7)$ & $0.4925(4)$ & 0 & 195(13) & $251(32)$ & $184(28)$ & $151(27)$ & $-5(23)$ & 0 & 0 \\
\hline $\mathrm{OH} 4$ & $0.2737(8)$ & $0.0375(4)$ & 0 & $179(12)$ & 272(34) & $165(28)$ & $100(25)$ & $24(24)$ & 0 & 0 \\
\hline OH5 & $0.0288(5)$ & $0.1008(3)$ & $-0.2509(6)$ & $159(8)$ & $220(22)$ & $113(18)$ & 146(19) & $24(16)$ & $-20(16)$ & $-6(15)$ \\
\hline OH6 & $0.2583(7)$ & $0.2256(4)$ & $-\hat{Y}$ & $157(12)$ & $252(29)$ & $118(26)$ & $103(23)$ & $18(23)$ & 0 & 0 \\
\hline $\mathrm{H} 1$ & $0.34(1)$ & $0.001(8)$ & 0 & +200 & & & & & & \\
\hline $\mathrm{H} 2$ & $-0.025(9)$ & $0.149(6)$ & $-0.25(1)$ & ${ }^{+} 200$ & & & & & & \\
\hline $\mathrm{H} 3$ & $0.18(1)$ & $0.230(8)$ & $-\hat{Y}$ & ${ }^{+} 200$ & & & & & & \\
\hline
\end{tabular}

* $U_{\text {eq }}=U_{\text {eq }} \AA^{2} \times 10^{4}$

** $U_{\mathrm{ij}}=U_{\mathrm{ij}} \AA^{2} \times 10^{4}$

+ fixed during refinement

valence sums at the $\mathrm{Cu} 1$ and $\mathrm{Cu} 2$ sites are 2.10 and $2.04 v u$, respectively. Inspection of the octahedral bond-angles (Table 3 ) reveals that all three of the $\mathrm{Cu}^{2+} \phi_{6}$ octahedra are significantly distorted, presumably owing to steric constraints.

The structure contains one symmetrically distinct $\mathrm{Mo}^{6+}$ position. The $\mathrm{Mo}^{6+}$ cation is coordinated by four $\mathrm{O}^{2-}$ anions in a slightly distorted tetrahedral arrangement, with a $<\mathrm{Mo}^{6+}-\mathrm{O}>$ bond-length of $1.757 \AA$. Both the $<\mathrm{Mo}^{6+}-\mathrm{O}>$ bond-length and the sum of bond valences incident at the site $(6.01 \mathrm{vu})$ indicate that the site is occupied only by $\mathrm{Mo}^{6+}$.

\section{Structure connectivity}

The (4+2)-distorted $\mathrm{Cu} 2 \phi_{6}$ and $\mathrm{Cu} 3 \phi_{6}$ octahedra share trans equatorial edges to form rutile-like chains of alternating $\mathrm{Cu} 2 \phi_{6}$ and $\mathrm{Cu} 3 \phi_{6}$ octahedra that extend along [001] (Fig. 1). The $\mathrm{Cu}_{1} \phi_{6}$ octahedra share trans apical-equatorial edges, also forming rutile-like chains that extend along [001] (Fig. 1). The chains of $\mathrm{Cu} 2 \phi_{6}$ and $\mathrm{Cu} 3 \phi_{6}$ octahedra are linked on two sides to chains of $\mathrm{Cu} 1 \phi_{6}$ octahedra by the sharing of octahedral edges, resulting in triple chains that extend along [001] (Fig. 1). The $c$ unit-cell length is controlled by the repeat distance of the triple chain of octahedra. The $\mathrm{MoO}_{4}$ tetrahedra are linked to either side of the triple chain of $\mathrm{Cu}^{2+} \phi_{6}$ octahedra by incorporating equatorial corners of alternate pairs of $\mathrm{Cu} 1 \phi_{6}$ octahedra, and the $\mathrm{MoO}_{4}$ tetrahedra on either side of the triple chain are coincident (Fig. 1).

Projection of the structure along [001] shows the nature of the linkages between adjacent triple chains of edge-sharing $\mathrm{Cu}^{2+} \phi_{6}$ octahedra (Fig. 2). Each triple chain is two-connected to $\mathrm{MoO}_{4}$ tetrahedra on either side, as illustrated in Fig. 1. Each $\mathrm{MoO}_{4}$ tetrahedron also shares one of its two remaining ligands with octahedra of each of two adjacent triple chains, resulting in a mixed tetrahedral-octahedral framework structure. According to the structural hierarchy proposed for $\mathrm{Cu}^{2+}$ oxysalt minerals by Eby and Hawthorne (1993), the structure of szenicsite can be classed as a $M=M-T$ framework.

\section{Relationship to other species}

Lindgrenite, $\mathrm{Cu}_{3}\left(\mathrm{MoO}_{4}\right)_{2}(\mathrm{OH})_{2}$, is chemically similar to szenicsite, with a $\mathrm{Cu}$ :Mo ratio of $3: 2$, as opposed to a $\mathrm{Cu}$ :Mo ratio of 3:1 in szenicsite. The structure of lindgrenite contains strips of edge-sharing $\mathrm{Cu}^{2+} \phi_{6}$ octahedra that are parallel to [001] and are two octahedra wide (Hawthorne and Eby, 1985). The strips of octahedra are crosslinked by sharing octahedral corners with $\mathrm{MoO}_{4}$ tetrahedra, resulting in a tetrahedral-octahedral framework that is similar to that of szenicsite (Fig. 3a). 

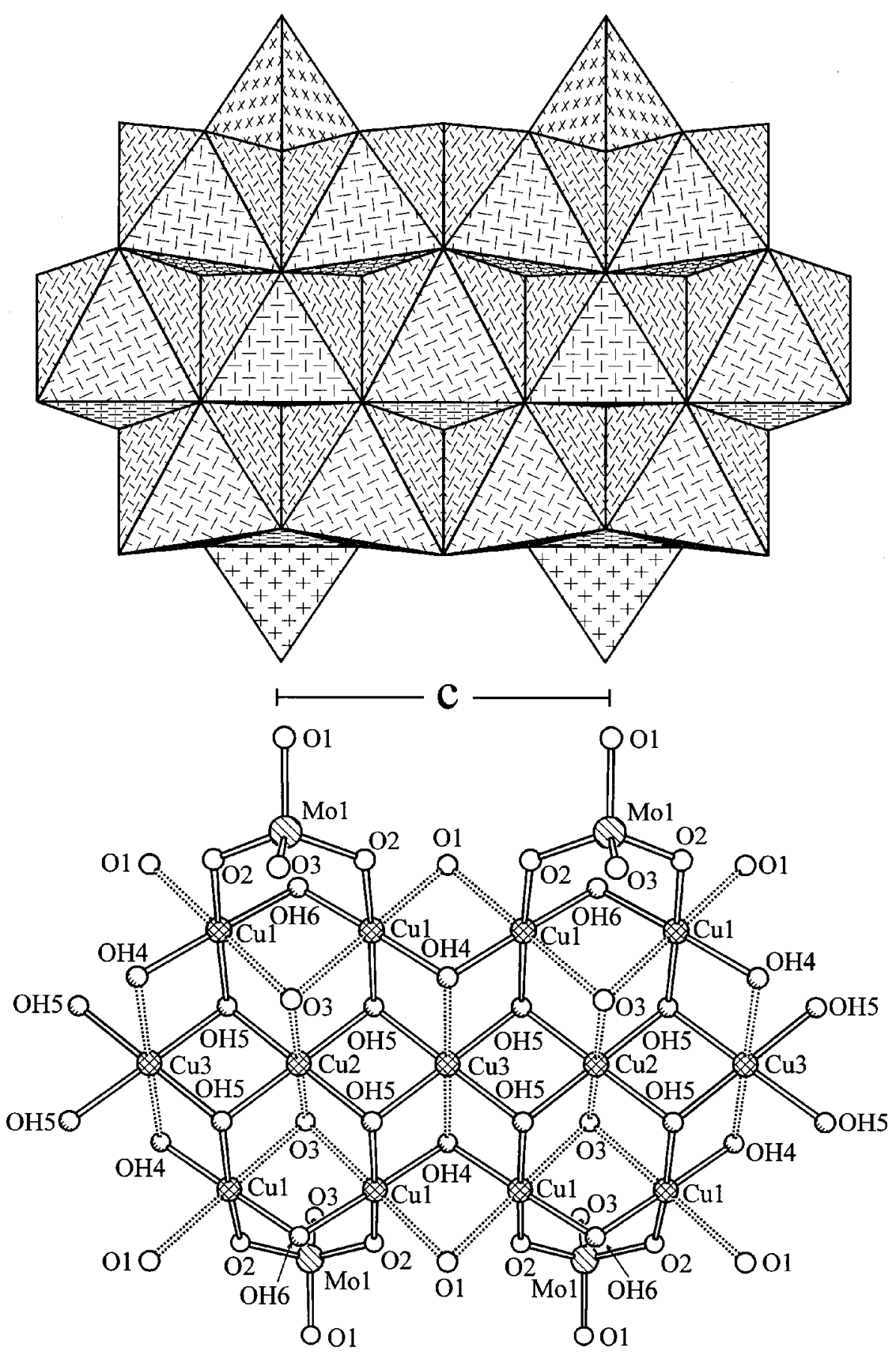

FIG. 1. The triple chain of edge-sharing $\mathrm{Cu}^{2+} \phi_{6}$ octahedra in the structure of szenicsite projected along [110]. The $\mathrm{Cu}^{2+} \phi_{6}$ octahedra are shaded with a herring-bone pattern and the $\mathrm{MoO}_{4}$ tetrahedra are shaded with crosses. Equatorial and apical $\mathrm{Cu}^{2+}-\phi$ bonds are illustrated with solid and broken lines, respectively. 


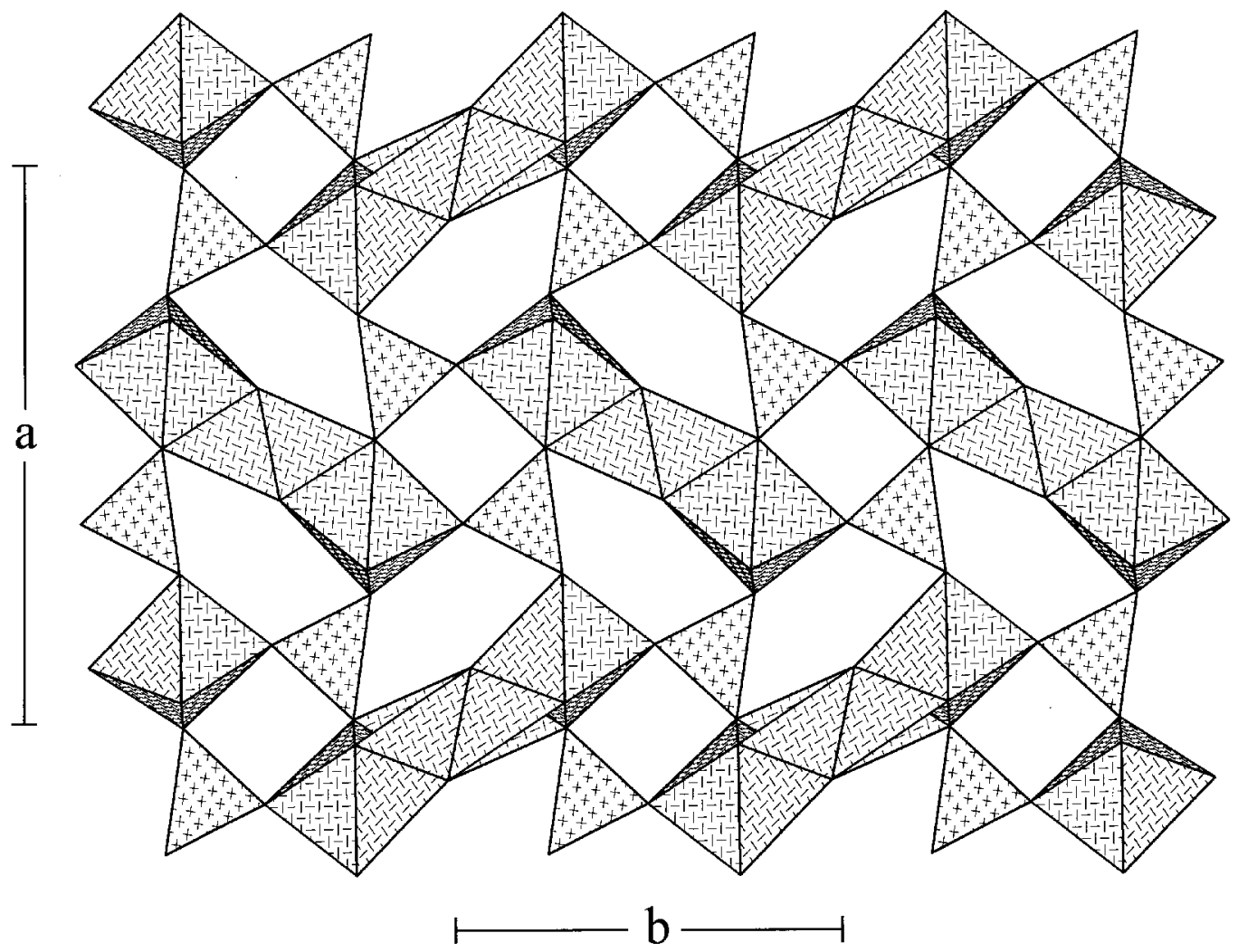

Fig. 2. The structure of szenicsite projected along [001]. Legend as in Fig. 1.

Antlerite, $\mathrm{Cu}_{3} \mathrm{SO}_{4}(\mathrm{OH})_{4}$, is the sulphate chemical analogue of szenicsite, and has similar unit-cell dimensions: $a=8.244(2), b=6.043(1), c$ $=11.987(3) \AA$, but the space group Pnma (Hawthorne et al., 1989). The structure of antlerite is shown projected along [010] in Fig. $3 b$. The structure contains triple chains of edge-sharing $\mathrm{Cu}^{2+} \phi_{6}$ octahedra that are crosslinked by tetrahedral-octahedral vertex sharing to form a framework structure (Hawthorne et al., 1989 ) which is very similar to that of szenicsite, as can be seen by comparing Fig. 2 and $3 b$.

The triple chains of $\mathrm{Cu}^{2+} \phi_{6}$ octahedra that occur in the structures of szenicsite and antlerite are compared in Fig. 4. The triple chains of $\mathrm{Cu}^{2+} \phi_{6}$ octahedra are identical in each structure, but the mode of attachment of the $(\mathrm{Mo}, \mathrm{S}) \mathrm{O}_{4}$ tetrahedra results in different structures. In the szenicsite chain, the $\mathrm{MoO}_{4}$ tetrahedra that are attached to either side of the triple chain are coincident (Fig. 4a); whereas, in the antlerite chain, the $\mathrm{SO}_{4}$ tetrahedra attached to either side of the triple chain are staggered (Fig. $4 b$ ), resulting in the space group Pnma for the antlerite structure, as opposed to Pnnm for the szenicsite structure. Hawthorne et al. (1989) noted that the attachment of $\mathrm{SO}_{4}$ tetrahedra to the triple chain requires substantial distortion of the $\mathrm{Cu}^{2+} \phi_{6}$ octahedra, and attributed the observed configuration of $\mathrm{SO}_{4}$ tetrahedra to a cooperative distortion such that the shortening of alternating vertex separations on one side of the chain spontaneously produces an offset distortion of the other side of the chain, as can be seen in Fig. $4 b$. However, in the case of the szenicsite chain, the larger $\mathrm{MoO}_{4}$ tetrahedra are attached to the triple chains without significant distortion of the $\mathrm{Cu}^{2+} \phi_{6}$ octahedra, thus a staggered arrangement of $\mathrm{MoO}_{4}$ tetrahedra on either side of the triple chain is not necessary. 

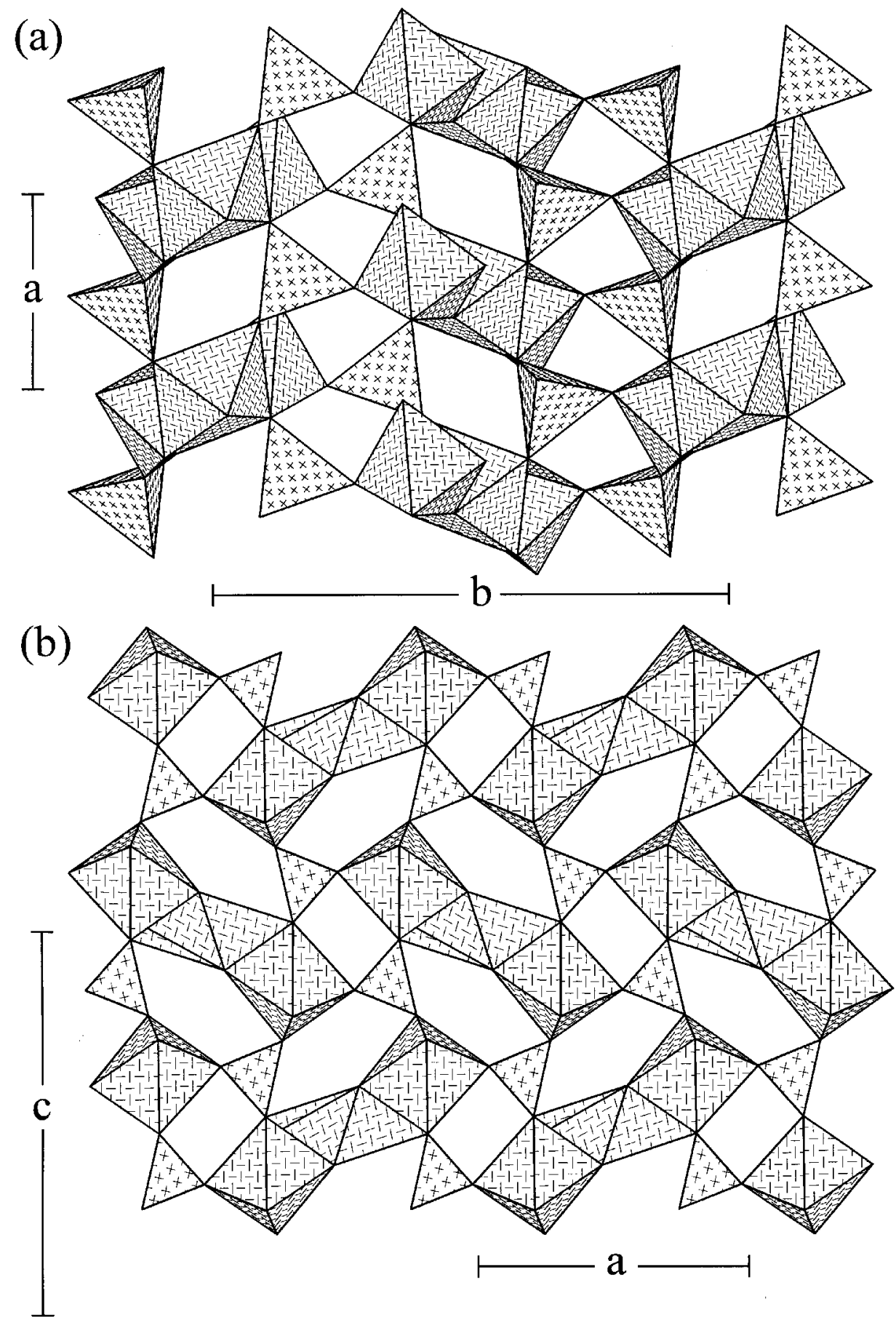

FIG. 3. The structures of $\mathrm{Cu}^{2+}$ oxysalts that are related to szenicsite. (a) the structure of lindgrenite projected along [001], (b) the structure of antlerite projected along [010]. $\mathrm{SO}_{4}$ tetrahedra are shaded with crosses in (b), otherwise legend as in Fig. 1. 

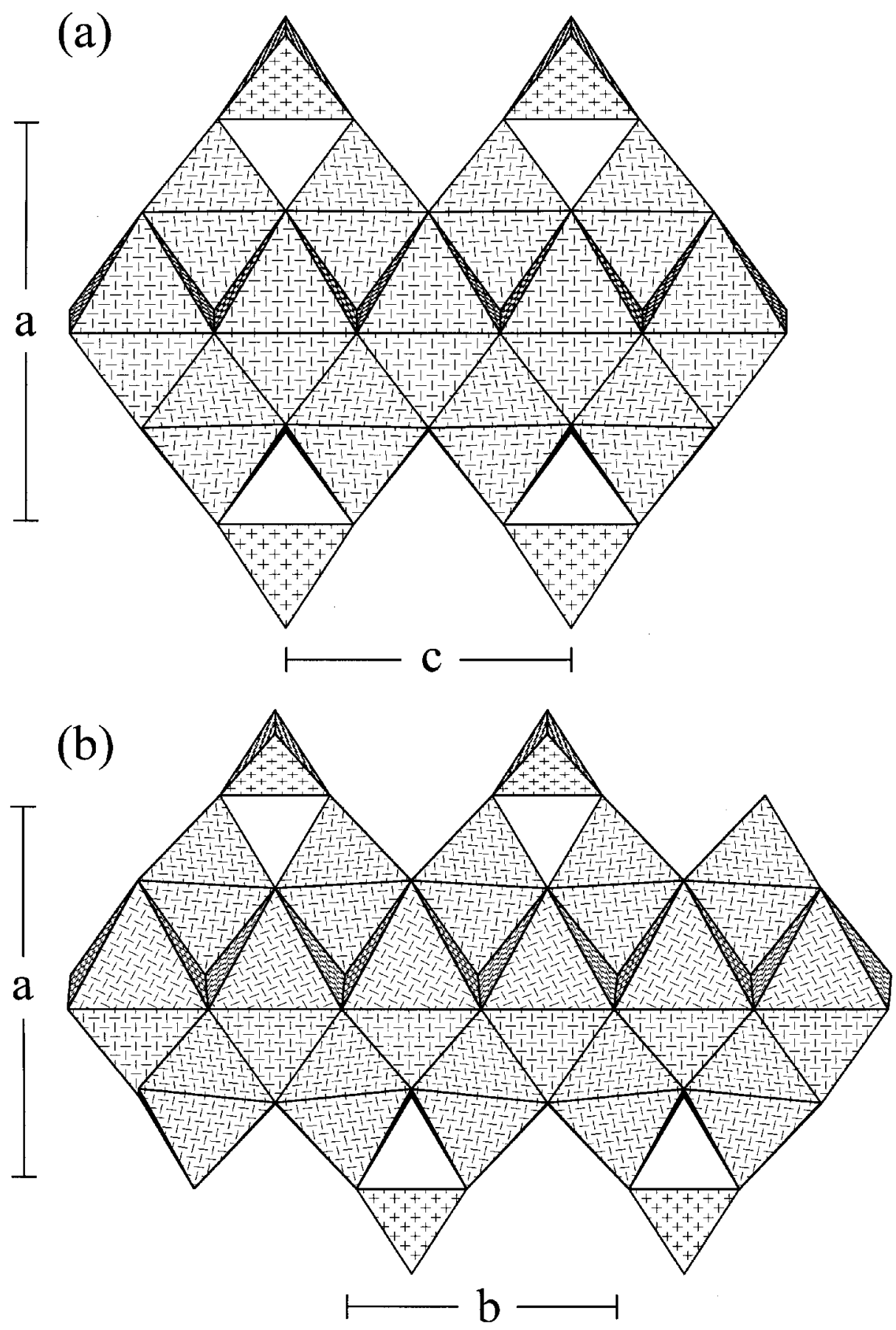

FIG. 4. Comparison of the triple chains of edge-sharing $\mathrm{Cu}^{2+} \phi_{6}$ octahedra that occur in $(a)$ szenicsite, and $(b)$ antlerite. Legend as in Fig. 3. 
TABLE 3. Selected interatomic distances $(\AA)$ and angles $\left({ }^{\circ}\right)$ for szenicsite

\begin{tabular}{|c|c|c|c|}
\hline Cu1-OH6 & $1.921(3)$ & $\mathrm{Cu} 3-\mathrm{OH} 5, \mathrm{e}, \mathrm{g}, \mathrm{h}$ & $1.996(4) \times 4$ \\
\hline $\mathrm{Cu} 1-\mathrm{OH} 4$ & $1.930(4)$ & $\mathrm{Cu} 3-\mathrm{OH} 4, \mathrm{~h}$ & $2.284(4) \times 2$ \\
\hline $\mathrm{Cu} 1-\mathrm{O} 2 \mathrm{a}$ & $2.049(5)$ & $<\mathrm{Cu} 3-\phi>$ & 2.092 \\
\hline $\mathrm{Cu} 1-\mathrm{OH} 5$ & $2.082(4)$ & & \\
\hline $\mathrm{Cu} 1-\mathrm{O} 1$ & $2.284(4)$ & Mo-O1 & $1.753(5)$ \\
\hline $\mathrm{Cu} 1-\mathrm{O} 3 \mathrm{~b}$ & $2.326(4)$ & $\mathrm{Mo}-\mathrm{O} 2, \mathrm{~g}$ & $1.757(4) \times 2$ \\
\hline \multirow[t]{2}{*}{$<\mathrm{Cu} 1-\phi>$} & 2.099 & Mo-O3 & $1.760(6)$ \\
\hline & & $<\mathrm{Mo}-\mathrm{O}>$ & 1.757 \\
\hline $\mathrm{Cu} 2-\mathrm{OH} 5, \mathrm{c}, \mathrm{d}, \mathrm{e}$ & $1.988(4) \times 4$ & & \\
\hline $\mathrm{Cu} 2-\mathrm{O} 3 \mathrm{~b}, \mathrm{f}$ & $2.368(6) \times 2$ & $\mathrm{OH} 5, \mathrm{~d}-\mathrm{Cu} 2-\mathrm{OH} 5 \mathrm{c}, \mathrm{e}$ & $180 \times 2$ \\
\hline \multirow[t]{2}{*}{$<\mathrm{Cu} 2-\phi>$} & 2.115 & $\mathrm{OH} 5, \mathrm{c}-\mathrm{Cu} 2-\mathrm{OH} 5 \mathrm{e}, \mathrm{d}$ & $80.8(2) \times 2$ \\
\hline & & $\mathrm{OH} 5, \mathrm{c}-\mathrm{Cu} 2-\mathrm{OH} 5 \mathrm{~d}, \mathrm{e}$ & $99.2(2) \times 2$ \\
\hline OH6-Cu1-OH4 & $178.4(3)$ & $\mathrm{OH} 5, \mathrm{c}, \mathrm{d}, \mathrm{e}-\mathrm{Cu} 2-\mathrm{O} 3 \mathrm{~b}, \mathrm{f}$ & $84.3(2) \times 4$ \\
\hline OH6-Cu1-O2a & $88.8(2)$ & $\mathrm{OH} 5, \mathrm{c}, \mathrm{d}, \mathrm{e}-\mathrm{Cu} 2-\mathrm{O} 3 \mathrm{~b}, \mathrm{f}$ & $95.6(2) \times 4$ \\
\hline OH6-Cu1-OH5 & $93.9(2)$ & $\mathrm{O} 3 \mathrm{~b}-\mathrm{Cu} 2-\mathrm{O} 3 \mathrm{f}$ & 180 \\
\hline OH6-Cu1-O1 & $94.1(2)$ & & \\
\hline OH6-Cu1-O3b & $86.6(2)$ & $\mathrm{OH} 5, \mathrm{~g}-\mathrm{Cu} 3-\mathrm{OH} 5 \mathrm{e}, \mathrm{h}$ & $180 \times 2$ \\
\hline $\mathrm{OH} 4-\mathrm{Cu} 1-\mathrm{O} 2 \mathrm{a}$ & $92.5(2)$ & $\mathrm{OH} 5, \mathrm{e}-\mathrm{Cu} 3-\mathrm{OH} 5 \mathrm{~g}, \mathrm{~h}$ & $99.6(2) \times 2$ \\
\hline $\mathrm{OH} 4-\mathrm{Cu} 1-\mathrm{OH} 5$ & $84.6(2)$ & $\mathrm{OH} 5, \mathrm{~g}-\mathrm{Cu} 3-\mathrm{OH} 5 \mathrm{e}, \mathrm{h}$ & $80.4(2) \times 2$ \\
\hline OH4-Cu1-O1 & $86.5(2)$ & $\mathrm{OH} 5, \mathrm{e}, \mathrm{g}, \mathrm{h}-\mathrm{Cu} 3-\mathrm{OH} 4, \mathrm{~h}$ & $75.7(2) \times 4$ \\
\hline $\mathrm{OH} 4-\mathrm{Cu} 1-\mathrm{O} 3 \mathrm{~b}$ & $92.7(2)$ & $\mathrm{OH} 5, \mathrm{e}, \mathrm{g}, \mathrm{h}-\mathrm{Cu} 3-\mathrm{OH} 4, \mathrm{~h}$ & $104.2(2) \times 4$ \\
\hline $\mathrm{O} 2 \mathrm{a}-\mathrm{Cu} 1-\mathrm{OH} 5$ & $172.1(2)$ & $\mathrm{OH} 4-\mathrm{Cu} 3-\mathrm{OH} 4 \mathrm{~h}$ & 180 \\
\hline $\mathrm{O} 2 \mathrm{a}-\mathrm{Cu} 1-\mathrm{O} 1$ & $89.1(2)$ & & \\
\hline $\mathrm{O} 2 \mathrm{a}-\mathrm{Cu} 1-\mathrm{O} 3 \mathrm{~b}$ & $89.3(2)$ & O1-Mo-O2,g & $109.3(2) \times 2$ \\
\hline OH5-Cu1-O1 & $98.1(2)$ & O1-Mo-O3 & $107.6(3)$ \\
\hline $\mathrm{OH} 5-\mathrm{Cu} 1-\mathrm{O} 3 \mathrm{~b}$ & $83.4(2)$ & $\mathrm{O} 2 \mathrm{~g}-\mathrm{Mo}-\mathrm{O} 2$ & $110.9(3)$ \\
\hline \multirow[t]{2}{*}{$\mathrm{O} 1-\mathrm{Cu} 1-\mathrm{O} 3 \mathrm{~b}$} & $178.3(2)$ & $\mathrm{O} 2, \mathrm{~g}-\mathrm{Mo}-\mathrm{O} 3$ & $109.8(2) \times 2$ \\
\hline & & $<\mathrm{O}-\mathrm{Mo}-\mathrm{O}>$ & 109.4 \\
\hline \multicolumn{4}{|l|}{ Possible $\mathrm{H}$ bonds } \\
\hline $\mathrm{OH} 4-\mathrm{H} 1$ & $0.8(1)$ & & \\
\hline $\mathrm{H} 1 \cdots \mathrm{O} 2 \mathrm{i}$ & $2.7(1)$ & $\mathrm{OH} 4-\mathrm{H} 1-\mathrm{O} 2 \mathrm{i}$ & $140(5)$ \\
\hline $\mathrm{H} 1 \cdots \mathrm{O} 2 \mathrm{j}$ & $2.7(1)$ & $\mathrm{OH} 4-\mathrm{H} 1-\mathrm{O} 2 \mathrm{j}$ & $140(5)$ \\
\hline $\mathrm{OH} 5-\mathrm{H} 2$ & $0.76(8)$ & & \\
\hline $\mathrm{H} 2 \cdots \mathrm{O} 1 \mathrm{f}$ & $2.5(1)$ & $\mathrm{OH} 5-\mathrm{H} 2 \cdots \mathrm{O} 1 \mathrm{f}$ & $139(5)$ \\
\hline $\mathrm{H} 2 \cdots \mathrm{O} 2 \mathrm{~g}$ & $2.6(1)$ & $\mathrm{OH} 5-\mathrm{H} 2 \cdots \mathrm{O} 2 \mathrm{~g}$ & $137(5)$ \\
\hline $\mathrm{OH} 6-\mathrm{H} 3$ & $0.6(1)$ & & \\
\hline $\mathrm{H} 3 \cdots \mathrm{OH} 5$ & $2.6(1)$ & OH6-H3 $\cdots$ OH5 & $117(5)$ \\
\hline $\mathrm{H} 3 \cdots \mathrm{OH} 5 \mathrm{~d}$ & $2.6(1)$ & OH6-H3 $\cdots$ OH5d & $117(5)$ \\
\hline
\end{tabular}

$\mathrm{a}=x+\hat{Y},-y+\hat{Y}, z-\hat{Y} ; \mathrm{b}=-x+\hat{Y}, y-\hat{Y},-z-\hat{Y} ; \mathrm{c}=-x,-y,-z-1 ; \mathrm{d}=x, y,-z-1 ; \mathrm{e}=-x,-y, z ; \mathrm{f}=x-\hat{Y},-y+\hat{Y}$, $z-\hat{Y} ; \mathrm{g}=x, y,-z ; \mathrm{h}=-x,-y,-z ; \mathrm{i}=\hat{Y}-x, y-\hat{Y}, \hat{Y}-z ; \mathrm{j}=\hat{\mathrm{Y}}-x, y-\hat{Y}, z-\hat{Y}$.

\section{Acknowledgements}

The sample used in this study was provided by $\mathrm{Mr}$ Andy Roberts of the Geological Survey of Canada.

\section{References}

Brese, N.E. and O'Keeffe, M. (1991) Bond-valence parameters for solids. Acta Crystallogr., B47, 192-7.
Burns, P.C. and Hawthorne, F.C. (1996) Static and dynamic Jahn-Teller effects in $\mathrm{Cu}^{2+}$ oxysalt minerals. Canad. Mineral., 34, 1089-105.

Eby, R.K. and Hawthorne, F.C. (1993) Structural relations in copper oxysalt minerals. I. Structural hierarchy. Acta Crystallogr., B49, 28-56.

Francis, C.A., Pitman, L.C. and Lange, D.E. (1997) Szenicsite, a new copper molybdate from Inca de Oro, Atacama, Chile. Mineral. Record., 28, 387-94. Hawthorne, F.C. and Eby, R.K. (1985) Refinement of 


\section{CRYSTAL STRUCTURE OF SZENICSITE}

TABLE 4. Bond-valence* analysis $(v u)$ for szenicsite

\begin{tabular}{llllll}
\hline & $\mathrm{Cu} 1$ & $\mathrm{Cu} 2$ & $\mathrm{Cu} 3$ & Mo & $\Sigma$ \\
\hline O1 & $0.19 \times 2 \rightarrow$ & & & 1.52 & 1.90 \\
O2 & $0.37 \times 2 \rightarrow$ & $0.16^{\times 2 \downarrow}$ & & $1.50 \times 2 \downarrow$ & 1.87 \\
O3 & $0.17 \times 2 \rightarrow$ & & $0.15^{\times 2 \downarrow}$ & 1.49 & 1.99 \\
OH4 & $0.51 \times 2 \downarrow$ & & & 1.17 \\
OH5 & $0.34 \times 2 \rightarrow$ & $0.43 \times 4 \downarrow$ & $0.42 \times 4 \downarrow$ & & 1.19 \\
OH6 & $0.52 \times 2.04$ \\
$\Sigma$ & 2.10 & 2.04 & 1.98 & 6.01 & \\
\hline
\end{tabular}

* bond-valence parameters from Brese and O'Keeffe (1991)

the crystal structure of lindgrenite. Neues Jahrb. Mineral., Mh., 234-40.

Hawthorne, F.C., Groat, L.E. and Eby, R.K. (1989) Antlerite, $\mathrm{Cu}_{3} \mathrm{SO}_{4}(\mathrm{OH})_{4}$, a heteropolyhedral wallpaper structure. Canad. Mineral., 27, 205-9.

Ibers, J.A. and Hamilton, W.C., eds. (1974) International Tables for X-Ray Crystallography,
IV. The Kynoch Press, Birmingham, UK.

Jahn, H.A. and Teller, E. (1937) Stability of polyatomic molecules in degenerate electronic states. Proc. Roy. Soc., Ser. A, 161, 220-36.

[Manuscript received 17 October 1997:

revised 23 December 1997] 